\title{
Selected Pisidian problems and the position of Pisidian within the Anatolian languages
}

\begin{abstract}
This paper presents three problems of Pisidian and their repercussions regarding the position of Pisidian within the Anatolian languages. These problems are the origin of the

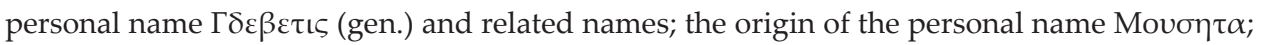
and the question whether the dative is attested in Pisidian. The paper argues that Pisidian is a Luwic language: not as a daughter of Hieroglyphic Luwian, but either as a part of the Carian - Lycian - Milyan dialect continuum or as a late form of Milyan.

Keywords: Pisidian, Luwic, Hieroglyphic Luwian, Milyan, personal names
\end{abstract}

\section{Introduction}

This paper presents three problems of Pisidian. They are connected by the fact that all of them have repercussions regarding the position of Pisidian within the Anatolian languages, which will be dealt with in $\S 5$. These problems are $(\S 2)$ the origin of the personal name $\Gamma \delta \varepsilon \beta \varepsilon \tau \iota \varsigma$

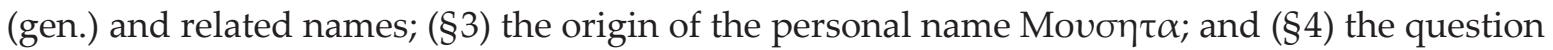
whether the dative is attested in Pisidian. ${ }^{1}$

\section{The origin of $\Gamma \delta \varepsilon \beta \varepsilon \tau \iota \varsigma$ (gen.) and related names}

$\Gamma \delta \varepsilon \beta \varepsilon \tau \iota \varsigma$ is attested as a patronym in genitive three times, twice as $\Gamma \delta \varepsilon \beta \varepsilon \tau \iota \varsigma$ (in the inscriptions Nos. N13, N14) and once as $\Gamma \delta \varepsilon \beta \varepsilon \tau \iota \varepsilon(N 12)$, on the last form see below (§4). As for the etymology of $\Gamma \delta \varepsilon \beta \varepsilon \tau \iota \varsigma$, Starke 1987: 258 n. 58 suggested that it represents a suffixed form of $\Gamma \delta \alpha \beta \alpha$ (N12) (gen. $Г \delta \alpha \beta \circ \varsigma$ (N10, N11 [bis], N27)). In turn, he connected $\Gamma \delta \alpha \beta \alpha$ with $\Gamma \delta \alpha \sigma \alpha \varsigma$ (gen.) (N7), what he identified with Lyc. xddaza- 'slave' (so already Lebrun 1983: 68 [not quoted by Starke], 2012: 362; see also Starke 1990: 363 n. 1295a [“wohl”]). ${ }^{2}$ Finally, he derived both forms from the root ${ }^{*} g d a-$, what he identified with the personal name Hadā attested in Old Assyrian transmission (Laroche 1966 No. 333). ${ }^{3}$

Starke's derivational chain is undoubtedly correct, however, the connection with the Lycian word is problematic, since one would expect $+\Gamma \delta \alpha \zeta \alpha \varsigma$ in Pisidian. Thus I find more merit in the suggestion of I. Hajnal, who, without quoting Starke's or Lebrun's derivation, assumed that $\Gamma \delta \alpha \beta \alpha$ originates in *hanta-wa- 'belonging to the front side' (Hajnal 1994: $147 \mathrm{n}$. 33-34 with 149 n. 40, 2000: 173; similarly Melchert 2013: 35 [hantawa- 'foremost, ruling', without quoting

${ }^{1}$ Pisidian inscriptions are quoted according to the numbering of Brixhe 2016b.

${ }^{2}$ Lebrun 2012: 360 cautiously compared $\Gamma \delta \alpha \beta \alpha$ with Lyc. $x d d a z a-$ 'slave' (without explaining the differences), but later (362), as quoted above, he compared $\Gamma \delta \alpha \sigma \alpha \varsigma$ with this Lycian word.

${ }^{3}$ For the sake of completeness, the outdated etymologies shall also be mentioned: $Г \delta \varepsilon \beta \varepsilon \tau \iota \varsigma$ is an ethnic name

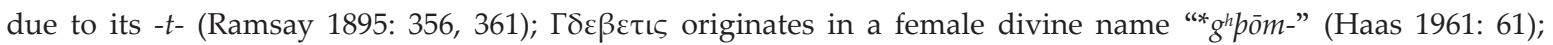
$\Gamma \delta \alpha \beta$ o is the Pisidian form of Greek $\Delta \tilde{\alpha}$ os (Ramsay 1895: 360).

Journal of Language Relationship • Вопросы языкового родства • 15/1 (2017) • Pp. 31-42 • ( ) The authors, 2017 
Hajnal or the alternative view] and Rieken - Sasseville 2014: 308-309 with different semantics). This suggestion can neatly explain all Pisidian forms:

a) $\Gamma \delta \varepsilon \beta \varepsilon \tau \iota \varsigma$ (gen.) corresponds to Lycian $x \tilde{n}$ tawat(i)-, Luwian handawat(i)- 'ruler' (see al-

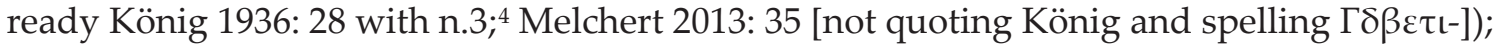

b) $\Gamma \delta \alpha \beta \alpha$ continues the adjective *hanta-wa- 'belonging to the front side' underlying to the verb *hantawa- 'to rule' (attested in Lycian as xñtawa-) underlying at the very end to handawat(i)-;

c) $\Gamma \delta \alpha \sigma \alpha \varsigma$ can regularly continue the frequent formation with -assa/i-, i.e. *hant-assa/i-. The $i$-mutation does not affect the genitive, and that is why there is no trace of the Umlaut expected on the base of $\Gamma \delta \varepsilon \beta \varepsilon \tau \iota \varsigma$.

Although only the explanation of $\Gamma \delta \alpha \sigma \alpha \varsigma$ represents a novelty here, it was important to quote the discussion due to its phonological implications that, in turn, contribute to determining the position of Pisidian among the Anatolian languages. Melchert 2013: 35 inferred the following sound changes:

1) regular voicing $t>d$ after nasal

2) loss of nasal

3) shift of $w>v / b$

4) assimilation ${ }^{*} k d->g d$ -

While the voicing $t>d$ after nasal is not remarkable in Anatolia, the loss of nasal (more precisely, ${ }^{*}-n d->-d-$ ) and the assimilation ${ }^{*} k d->g d$ - will have a specific role below (§5.2). ${ }^{5}$ Finally, to these changes one must add the $a>e$ Umlaut caused by the suffix $-t i-6$ as well as the syncope of the presumably unaccented vowel in the first syllable (cf. also Brixhe 2016b: 112).

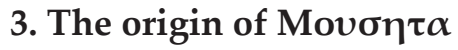

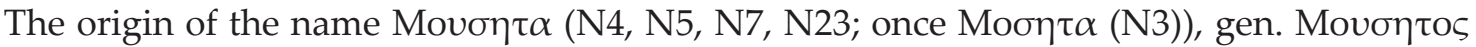

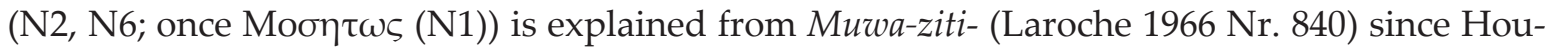
wink ten Cate 1961: 167.7

However, Melchert 2013: 39 recognized that Movon $\alpha$ cannot be a regular reflex of Muwaziti- due to the voiceless stop and the vowel written with an eta, to which one must add that the sigma cannot reflect $\left\langle\mathrm{Z}>\right.$, as it should be spelled with zeta (Schürr forthcoming). ${ }^{8}$ Melchert suggests that with the loss of the synchronic compound status (referring to the fact that Ziti-, as such, is not attested in the Iron Age), this name was remodelled after Greek masculine names in $-\alpha \tau \eta \varsigma /-\alpha \tau \alpha \varsigma$. It must be mentioned at this juncture, as Melchert himself pointed out,

\footnotetext{
${ }^{4}$ I owe this reference to Ignasi-Xavier Adiego.

${ }^{5}$ The "shift of $w>v / b$ ", i.e. the exact phonetic value of beta in these inscriptions requires a specific investigation that cannot be accomplished here.

${ }^{6}$ The consistent spelling of these names (and the Pisidian names in general) either with epsilon or with alpha proves that these must have been different phonemes and not a sheer "échange graphique" (contra Brixhe 2016b: 113) and, accordingly, they need a linguistic explanation, for which Umlaut is an obvious solution.

7 See also Zgusta 1963: 479; Starke 1987: 256 n. 51, 1999: cols. 531-532; Brixhe - Drew-Bear - Kaya 1987: 136; Brixhe 1988: 142, 143, 2016b: 115 (none of the last three quoting Houwink ten Cate or Zgusta); Adiego 1992: 32, 2007: 386 (here only “perhaps”); Hajnal 1995: 32 n. 10, 2000: 173 (without quoting anyone); Melchert 2013: 39 (without quoting anyone).

8 The problem of the voiceless stops was also recognized by Starke 1987: 256 n. 51, but he dismissed it without explanation. Adiego 1992: 32 n. 11 explains the vocalism with the names in ${ }^{\circ} \sigma \alpha \tau \eta \varsigma$, allegedly continuing names in -ziti, which is, however, obscurum per obscurius.
} 
that this name is attested not only in Pisidian, but also in Carian (Mwsat, Adiego 2007: 386)

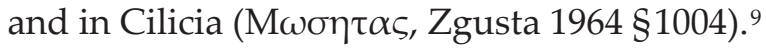

Schürr (forthcoming) disagreed with this suggestion, pointing out that these names did not become Greek, and Greek influence in a Carian name attested in Egypt in the $6^{\text {th }} \mathrm{c}$. BC as well as in a name attested in Pisidia in the $3^{\text {rd }} \mathrm{c}$. AD is not probable. Nevertheless, the names did not need to become fully Greek to absorb Greek influence, and Greek influence is absolutely possible both in $3^{\text {rd }} \mathrm{c}$. AD Pisidia (consider the Greek names with Greek inflectional endings in the inscriptions N10, N31, N34) as well as in Egypt in the $6^{\text {th }} \mathrm{c}$. BC, especially in view of the presence of Greek mercenaries together with the Carians, and that the name itself must have originated from Caria anyway.

The real problem with Melchert's explanation is that it is unlikely that the same remodelling would happen in three different and non-contiguous languages, i.e. in Carian, Pisidian and "Cilician" (probably a late form of Luwian). It is much more probable that it reflects a shared innovation, a shared type of suffixation, especially since as Luwic languages, these languages are closely related to one another. Moreover, a seemingly underlying Luwic *atta- suffix is not unknown in the Anatolian languages: it has an equivalent in Lydian in such wellknown names as Aly-attēs, Sady-attēs and even Maddu(w)-atta. The Carian name was already analysed as Mws-at by Schürr (forthcoming), who connects it with other Carian names show-

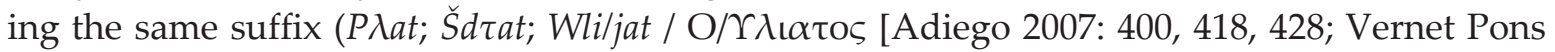
2012: 148-149]; $\Sigma \mathrm{t} \delta v \alpha \tau O \varsigma)$, but without providing an explanation for this suffix. ${ }^{10}$

However, Schürr (forthcoming) separates the Pisidian name, since the spelling with an eta instead of an alpha requires an explanation. In fact, this variation is attested in Pisidian, the "only" question is how to interpret the data. The examples are the following:

1) Eı $\alpha(N 9, N 14)$ vs. Eı $(N 1, N 37, N 48)$

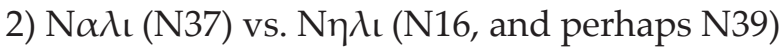

According to Schürr (forthcoming) $\mathrm{N} \alpha \lambda \mathrm{\iota}$ and $\mathrm{N} \eta \lambda \mathrm{\iota}$ are two variants of the same name, and the eta seems to reflect Umlaut due to the following /i/. While this cannot be excluded $a$ priori, the result of the only assured case of $i$-Umlaut shows epsilons (see $Г \delta \varepsilon \beta \varepsilon \tau \iota \varsigma$ above, $\S 2$ ), and epsilons and etas are not interchangeable (Brixhe 1987: 46-49, 2010: 232-233, cf. also 1988: 145). Furthermore, Brixhe - Özsait 2001: 164 cautiously argue that $N \alpha \lambda \iota$ and $N \eta \lambda \iota$ have nothing to do with each other, since $\mathrm{H}$ already had the value /i/ at that time (cf. also Brixhe 1987: 46-49, 1988: 139, 2010: 232) and thus these are derived by -li- from two different and well attested Lallnamen, $\mathrm{Na}$ and $\mathrm{Ni}$. Set aside that the precise date of these specific inscriptions is unknown, ${ }^{11}$ the situation is nevertheless more complex, for eta had not yet merged with /i/ in the 4th c. AD, when the Gothic, Old Georgian and Old Armenian alphabets were created (Allen 1987: 74-75, cf. also Starke 1987: 256 n. 49: [e] and [i]). ${ }^{12}$ In other words, the existence of two different names cannot be proven.

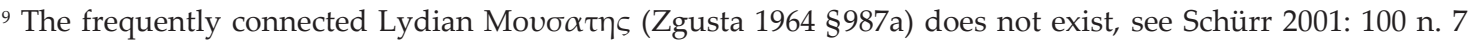
with ref.

${ }^{10}$ Vernet Pons 2012: 150 suggested deriving Wli/jat from a form with -ant-, but in this case we would expect *Wli/ja $\delta$ in Carian (*-nt- leads to Carian $\delta$, Adiego 2007: 260).

${ }^{11}$ As for No. 16, Ramsay 1895: 354 claimed that it is not possible to date the inscriptions N1-N16, but some of them may be Roman (followed by Borchhardt - Neumann - Schulz 1975: 68, who falsely claim that Ramsay dated these inscriptions based on the shapes of the letters). N37 was dated by the publishers to the 3rd c. AD (Brixhe - Özsait 2001: 156, 166), without providing any arguments.

${ }_{12}$ Melchert 2013: 39 also claims that eta was not an /i/, thus implicitly withdrawing his earlier interpretation when he transcribed the name as "Musita" (Melchert 1994a: 44, 1994b: 127). 
The case of the other name, Eı $\alpha$ / Eı, is also instructive (the problem of the spelling variation was already observed by Zgusta 1957: 582, who could not offer a solution). Although Brixhe 1988: 145, 2016b: 115 suggests that Ei is the Hellenised version, there is no reason to see a Hellenised form in this name. Since there is no external reason to motivate the alpha / eta variation in the spelling of Eı $\alpha$ / Eı and $N \alpha \lambda \iota / N \eta \lambda \iota$, the remaining possibility is that they represent a specific phoneme originating from /a/ that could not have been rendered by the Greek alphabet (perhaps an /æ/). Whatever the exact phonetic realization of this phoneme

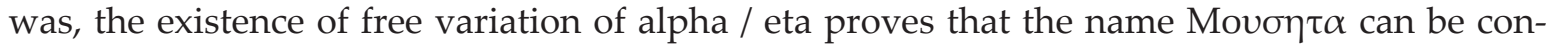
nected with Mws-at and the -atta-names regularly. ${ }^{13}$

\section{Is the dative attested in Pisidian?}

Three instances from the inscriptions N1 and N12 were suggested as attestations of dative in Pisidian. The inscription N12 (with a male on the relief) is as follows (in the generally ac-

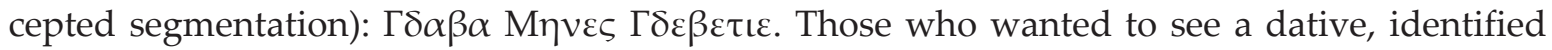
$\Gamma \delta \varepsilon \beta \varepsilon \tau \iota \varepsilon$ as the dative form (see already Sundwall 1913: 117; Zgusta 1957: 605-606, 1963: 480; Haas 1961: 61). However, $Г \delta \varepsilon \beta \varepsilon \tau \iota \varepsilon$ is obviously either a misspelling or the misreading of $\Gamma \delta \varepsilon \beta \varepsilon \tau \iota \varsigma$ (gen.), since it is in the position of the papponym. ${ }^{14}$ Note also that not a single instance of the almost fifty grave inscriptions known to date contain a "dedicatory" one (for the alleged exception of the inscription N1 see the following discussion). The inscription N1 on the tombstone of two men and a woman is as follows:

\section{$\delta \omega \tau \alpha \varrho \iota \mu о \sigma \eta \tau \omega \varsigma \varepsilon เ \eta \delta \omega \tau[\alpha] \varrho ı \varsigma \delta \omega \tau \alpha \varrho เ \varepsilon \nu \varepsilon เ \varsigma$}

It has been segmented in two different ways and interpreted in three different ways (Table 1):

Table 1. Suggested interpretations of the inscription N1

\begin{tabular}{|c|c|}
\hline 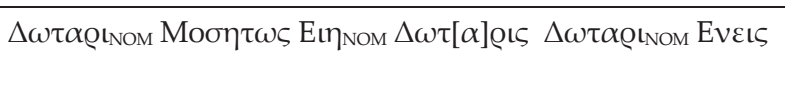 & $\begin{array}{l}\text { Metri 1958: 46; Brixhe 1988: 132-133, 136; Brixhe - } \\
\text { Özsait 2013: 231; Brixhe 2016b: 78-79 }\end{array}$ \\
\hline 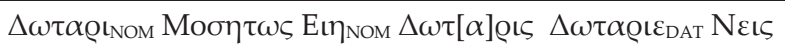 & Zgusta 1957: 606-607, 1963: 480 \\
\hline 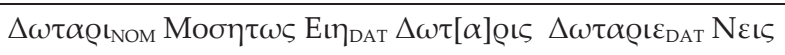 & Zgusta 1957: 606-607, 1963: 480; Starke 1987: 256-258 ${ }^{15}$ \\
\hline
\end{tabular}

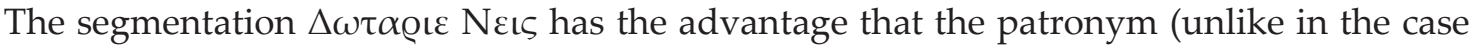

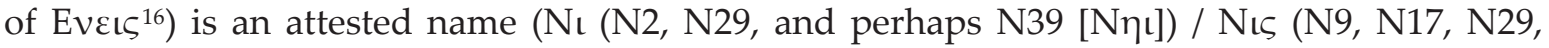
N42)). The interpretation with two datives has two problems: First, as Brixhe 1988: 145 rightly pointed out, Ein cannot represent a dative since it is written with an eta, not with an epsilon, and these letters are not interchangeable, as I have just mentioned above (Brixhe 1987: 47-49, 2010: 232-233, cf. also 1988: 145). The second problem is (which is still there if the construction is interpreted with only one dative) that this translation requires one or two deceased, but the relief shows three persons. Thus Starke was forced to assume that the tombstones were not

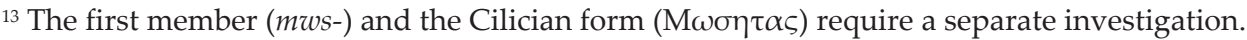

${ }^{14}$ It is a misspelling according to Ramsay 1895: 361 (implicitly); Brixhe - Drew-Bear - Kaya 1987: 149; and a misreading according to Brixhe - Özsait 2013: 231; cf. also Metri 1958: 47. Brixhe $2016 b: 83$ already transcribes it as $\Gamma \delta \varepsilon \beta \varepsilon \tau \iota \varsigma$ (cf. Brixhe 2016b: 120).

15 Similarly already Haas 1961: 61 (although segmenting $\Delta \omega \tau \alpha \varrho \iota$ Eveıs), and Lebrun 2012: 359,360 (cautiously: "peut-être").

${ }^{16}$ N41 may show a name Hves that might be connected with this name, but its segmentation is not assured and the connection is problematic phonologically, cf. Brixhe 2016b: 40-41, 94. 
prepared individually but bought from a prepared set and the inscription was engraved only later. Although this is not impossible, it would definitely be strange and note that there is no other instance for a dative (his other example with $\Gamma \delta \varepsilon \beta \varepsilon \tau \iota \varepsilon$ is false, see above). But even if a mistaken combination could have happened, it is obvious from a methodological point of view that those solutions should be preferred where the inscription and the depiction are consistent with each other. ${ }^{17}$ Since the tombstone has been lost, Starke also tries to undermine the credibility of Ramsay's descriptions (1987: 257 n. 54), even though the problem at hand concerns only the depth of the incised letters, not the overall description or the distinctions between men and women. ${ }^{18}$ Finally, Starke's family reconstruction (mother $\Delta \omega \tau \alpha \varrho \mathrm{L}$, child Eı daughter $\Delta \omega \tau \alpha \varrho \iota \varepsilon$ from the second marriage of $\Delta \omega \tau \alpha \varrho$ ) again absolutely contradicts the gravestone (two females and one male instead of the depicted two males and one female).

Thus two possibilities remain: first is the reading and translation of Metri and Brixhe

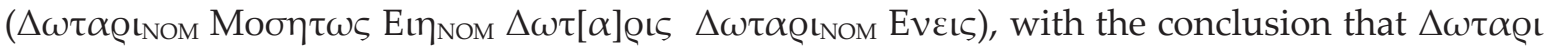
is a male name, Eı is a female one (unless $\Delta \omega \tau \alpha \varrho \iota$ can be used for both genders [Brixhe 1988: $132-133,136$ also allowed that $\Delta \omega \tau \alpha \varrho$, may be both a male and a female name, which was denied by Starke 1987: 257, because he believes this can happen only with Lallnamen and hypocoristic names], but one of the $\Delta \omega \tau \alpha$ Qts must be male in this case, too). A second possibility is

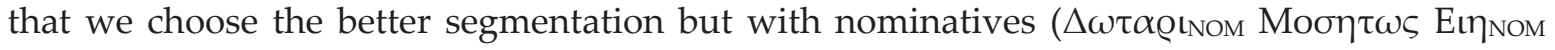
$\left.\Delta \omega \tau[\alpha] \varrho \iota \varsigma \Delta \omega \tau \alpha \varrho \iota \varepsilon_{\text {NOM }} N \varepsilon \iota \varsigma\right)$. Due to the formal difference between $\Delta \omega \tau \alpha \varrho$ and $\Delta \omega \tau \alpha \varrho \iota \varepsilon$ this would probably mean that the males are $\Delta \omega \tau \alpha \varrho$ and Eı and the female is $\Delta \omega \tau \alpha \varrho \iota \varepsilon$ (this gender attribution has already been suggested by Zgusta 1957: 606-607, 1963: 480). Both interpretations allow to explain the tombstone as a family tombstone (in the first case one of the $\Delta \omega \tau \alpha$ Q ss is the father, the other one is the husband of Eı ${ }^{19}$ in the other case there is a father, $\Delta \omega \tau \alpha \varrho$, and his wife $\Delta \omega \tau \alpha \varrho \varepsilon$, and their child Eı $)$, thus a decision cannot be made on these grounds (although the latter solutions seems to me a more typical family tombstone and thus a more probable solution). But whichever solution is the correct one, it is clear that there is no assured attestation of dative in the Pisidian inscriptions.

\section{The position of Pisidian among the Anatolian languages}

\subsection{The proposals until now}

Pisidian was not included in Oettinger 1978 on the internal classification of the Anatolian languages, because at that time he did not consider its Anatolian status proved (1978: 75 n. 9), and it is not included in the forthcoming paper of E. Rieken on Anatolian dialectology either, since it is too poorly attested. Nevertheless, some scholars formulated an opinion regarding this issue.

17 The reliefs and the inscriptions published until 2016 were overall consistent (there might have been only one exception [Starke's other example with $\Gamma \delta \varepsilon \beta \varepsilon \tau \iota \varepsilon$ is false, see above], a Greek inscription (Pó $\delta \omega v$,

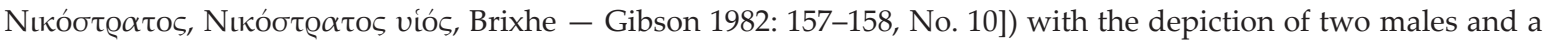
female, which, however, may be explained by the simple assumption of a phonetically well motivated spelling

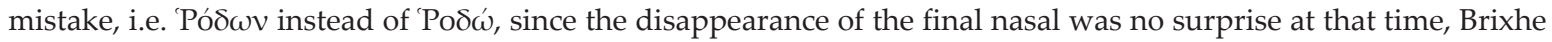
- Gibson 1982: 158 n. 50). Nevertheless, as an anonymous reviewer kindly reminded me, the new inscriptions published in Brixhe 2016 contain several inconsistent cases, that require further research.

18 The options mentioned in Ramsay 1895: 357 ( $\Delta \omega \tau \alpha \varrho\llcorner\varepsilon v \varepsilon \iota \varsigma$ as an ethnic / political unit name or yet another genitive) is not compatible with the three deceased, since then only two names remain in nominative ( $\Delta \omega \tau \alpha \varrho \mathrm{L}$ and Eı $)$.

${ }_{19}$ Theoretically one could imagine that the two male $\Delta \omega \tau \alpha$ Q ss were two husbands of Eı, which is not impossible, but a shared tombstone does not sound very probable. 
First, Zgusta 1963: 480-481 claimed that Pisidian is a Luwic language (to use the modern terminology) and within this group it is more closely related to Lycian. He based his opinion on the geographical position of Pisidian, the origin of Pisidian names, and alleged parallels between the Lycian and Pisidian nominal paradigms, i.e. zero ending in nominative, the similarity of the genitive (both to be discussed below), and the similarity of the dative ending (Lycian -ije vs. Pisidian -e), but we have already seen that this dative ending does not exist (§4).

Second, Neumann (1978: 874 n. 6, 880 n. 11) suggested cautiously (“dürfte”) that Pisidian and Sidetic stand closest to each other. He called attention to a passage in Livius (35, 13 " $a d$ Pisidas, qui circa Sidam incolunt") on the one hand, and to the zero ending of nominative singular and the $-s$ ending of the genitive singular shared by Pisidian, Sidetic and partly Lycian on the other hand. Although the remark of Livius is highly interesting, nothing follows from it, since it does not specify the relationship of the Pisidians and the Sidetans, and we do not know anything about the history of this situation either. In other words, this is a very interesting possibility, but a linguistic analysis is still needed to confirm or to reject it. The morphological arguments will be dealt with in detail in the following.

Third, Starke 1999 (cf. also 1997: 457, 468) argued in detail for the Luwian character of Pisidian, more precisely that it continues the Hieroglyphic Luwian dialect (or in current terminology, the Iron Age Luwian dialect). Probably this is the basis of the statements of Melchert 2003a: 10, 2003b: 177 (who believes that Pisidian may be a late form of Luwian or a distinct dialect, but it is impossible to determine) and Lebrun 2012: 353 (who considers Pisidian a "direct heiress" to Luwian), but neither of them quote their sources. Starke's methodology is not clear, but he speaks about four "gemeinluwische" innovations shared by Pisidian, Lycian and Milyan, which implies a closer relationship, either in genetic or in areal sense as well as about two characteristics common with Hieroglyphic Luwian (1999: cols. 530, 532). The four innovations are as follows:

a) $\breve{a}>$ e (Pisidian $<\varepsilon, \eta>$ ) (also in Starke 1987: 256 n. 49)

b) $s>\varnothing / V_{-} \#$

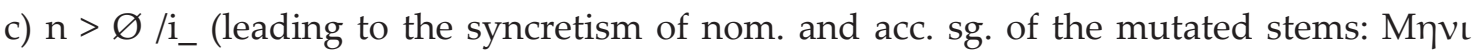

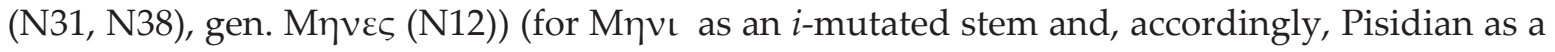
Luwian language see already Starke 1987: 256);

d) abandonment of the -hhi-conjugation

Unfortunately, two of Starke's arguments are wrong, and one has a different explanation: First, it cannot be judged, if Pisidian abandoned the -hhi-conjugation or not, since not a single Pisidian verb form has been identified until now (the new inscriptions from Selge and Kesme and Değirmenözü [Brixhe 2016b: S1-S4 with refs.]), unknown at the time of Starke's paper, may include verb forms but they are still unintelligible, for a segmentation attempt of S2 see now Adiego 2016).

Second, the name Mpvı is obviously theophoric, ${ }^{20}$ but the $i$-mutation is not a derivational suffix, thus this - $i$ - should have another explanation, for instance the ubiquitous -iya- adjectival / appurtenance suffix with the similarly ubiquitous contraction. Moreover, the genitive is at-

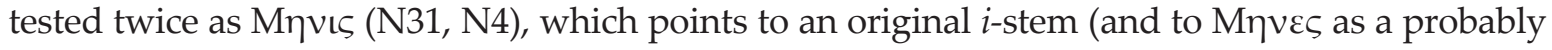
secondary spelling / pronunciation; it is an inverse spelling according to Brixhe 1988: 144-145). But even if we assume for the sake of the argument that Mpvı is an i-mutated stem, nothing proves that the nominative and the accusative singular merged, since there is no identified accusative until now. Moreover, nothing points to the loss of a final /n/ after /i/ in Pisidian.

${ }^{20}$ Brixhe - Drew-Bear - Kaya 1987: 150; Brixhe - Özsait 2001: 164; Lebrun 2012: 360 (contra Starke 1987: 256 n. 50a connecting it with Luwian compound names with Mana- as their first member). 
Third, there is no evidence for a general change $\breve{a}>e$ in Pisidian. On the one hand, as we have seen above $(\S 2)$, secondary $<\varepsilon>$ is due to $i$-Umlaut (and the alpha/eta change probably has a completely different explanation, see §3). On the other hand, there are many Pisidian words that maintained their /a/ (cf. e.g. below under the discussion of the origin of the Pisidian vocabulary).

Thus, only the loss of postvocalic final /s/ remains as an argument - but this is an argument that separates Pisidian from Hieroglyphic Luwian. Although this loss can be explained as secondary from Hieroglyphic Luwian final/-s/, of course, this can be done only if the relationship of the two languages is otherwise proved. The identification with Hieroglyphic Luwian is, however, based only on the following characteristics:

a) There is a genitive case in Pisidian, thus it cannot continue Cuneiform Luwian (or with today's terminology, Kizzuwatna Luwian);

b) The contraction $y a>i$ in the oblique cases of the $i$-stems is shared only by Hieroglyphic Luwian and Pisidian, see gen. $\Delta \omega \tau[\alpha]$ @ıs.

The problem with these two arguments is that they are not characteristic enough. The genitive case has been retained in all the Luwic languages, save Kizzuwatna Luwian, thus it does not tell us too much about the position of Pisidian. This specific contraction is just yet another case of the widespread -iya- >-i- contraction and thus, again, it is not helpful.

Finally, Starke 1987: 259 argued that the Pisidian word for 'girl' is an $i$-stem and not $a$ stem, as in Lycian, thus it stands closer to Cuneiform Luwian (but not continuing, as per above). This is based on his identification of $\Delta \omega \tau \alpha \varrho \mathrm{L}$ as the Pisidian word for 'daughter' (Starke 1987: 258-259, 1990: 347; followed by Schürr 1999: 25 [who later retracted it] and Lebrun 2012: 360). However, this identification is very probably wrong, since this name must refer to a male, at least once (see $\S 4$ above, inscription N1) and also appears in the compound

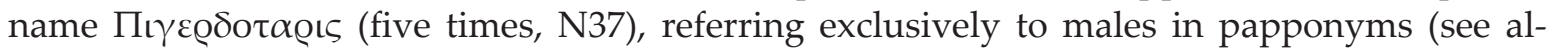
ready Schürr 2006: 1560 n. 2). Note also, that a derivation from Proto-Indo-European *dhuégh $t r$ / $d^{h} u g h_{2} t r$ - 'daughter' (on the form see Kloekhorst 2011) is also problematic phonologically, due to the initial consonant as well as the different vocalism, and Starke has not provided any explanation for these. In other words, this word cannot be used as an argument the way Starke did. But even if it means 'girl', it shows the suffix - $i$ - from -iya-, which does not exclude the possibility of an $a$-stem.

To sum up, there is no argument for identifying Pisidian as a daughter language of Hieroglyphic Luwian. Actually, if someone looks at the map this is not surprising at all: Pisidian was spoken a long way away from assured Luwian speaking territories (separated by Lycaonia), thus the question whether Pisidian originates from Hieroglyhic Luwian does not even come up.

\subsection{The material}

The classification of Pisidian must obviously remain very tentative due to the lack of evidence. This is especially true because the sparse evidence at hand does not allow using the classical method, i.e. detecting shared exclusive (morphological) innovations. Currently we can work only with shared isoglosses that admittedly have lower demonstrative value. In the following these isoglosses will be presented from the field of inflectional and derivational morphology as well as historical phonology (summarized in a table at the end).

Within the inflectional morphology, the zero nominative and the sibilant genitive ending in the singular are paralleled by Milyan, Carian and Sidetic (note that the dative singular and the $i$-mutation are not attested in Pisidian, as per above and §4). While the prehistory of the nominative is beyond doubt (loss of final $-s$ ), this is not the case with the genitive, except that 
the final $-s$ of the genitive cannot continue an earlier final $-s$, i.e. it must originate in ${ }^{*}-s X .{ }^{21}$ Melchert repeatedly assumed the suffix of the genitival adjective to be *asso/i-, where the deletion of the final $-s$ would have been followed by the deletion of the last unaccented vowel (1994a: 44-45, 1994b: 127, similarly but cautiously Hajnal 2000: 182); Melchert 2012: 278 n. 10 later allowed the possibility of the genitive ending *-oso as well. This possibility was chosen already by Brixhe 1988: 142-143, who rightly pointed out the lack of agreement between the possessor and possessed which would be a requirement in the case of the genitival adjective (cf. also Brixhe 2016a: 33). Nevertheless, Brixhe - Özsait 2001: 161-162 (cf. also Brixhe 2016a: 33) suggested yet another source, the genitive ending attested in Cuneiform Luwian -ašši, Hieroglyphic Luwian /-as(s)i/, Carian -ś, Sidetic -s, and probably reflecting PIE *-osyo (Melchert 2012: 278-279; cf. also Yakubovich 2010: 39-45). It is hard to choose between these alternatives from a Pisidian point of view, since both are possible, as long as we do not know more about the loss of the final vowels in the prehistory of Pisidian.

As for the derivational morphology, the suffix *-iya- in - $i$ - is simply too ubiquitous and the suffix -at- is attested also in Lydian (cf. above, §3), thus, again, it is not helpful. ${ }^{22}$ If the analysis of $\Delta \omega \tau \alpha \varrho \iota \varepsilon$ as a derivation from $\Delta \omega \tau \alpha \varrho$ s suggested above $(\S 4)$ turns out to be correct, then there is a suffix -e-too, whose prehistory, however, is completely unclear at the moment.

While the historical phonology of Pisidian shows some widespread and thus not helpful changes (the contraction of -uwa- and -iya-), as well as specifically Pisidian changes (*-nt- >- $d-$; the epenthetic vowel in ouper-, piger-, for the identification of this change see Adiego 2012: 20), there are some more restricted changes shared by other Anatolian languages, which can be summarized as follows (cf. Table 2):

Table 2. Shared isoglosses of Pisidian

\begin{tabular}{l|c|c|c|c}
\hline \multicolumn{1}{c|}{ Pisidian } & Milyan & Lycian & Carian & Sidetic \\
\hline nom. sg. ${ }^{-} s>-\varnothing$ & $\mathrm{x}$ & - & $\mathrm{x}$ & $\mathrm{x}$ \\
\hline gen. sg. $-s$ & $\mathrm{x}$ & - & $?$ & $?$ \\
\hline $\begin{array}{l}\text { syncope of an } \\
\text { unaccented vowel }\end{array}$ & $\mathrm{x}$ & $\mathrm{x}$ & $\mathrm{x}$ & - \\
\hline $\begin{array}{l}a>e \text { Umlaut by } / \mathrm{i} / \\
\text { laryngeal } *-,-g-\end{array}$ & $\mathrm{x}$ & $\mathrm{x}$ & - & $?$ \\
\hline $\begin{array}{l}\text { no lenition in the } \\
\text { suffix }-t i-\end{array}$ & $\mathrm{x}$ & $\mathrm{x}$ & $?$ & $?$ \\
\hline
\end{tabular}

a) the presumably unaccented first vowel was syncopated (just like in Lycian, Milyan and, perhaps, in Carian) - or at least the words of these languages originating in *hant- share the same history;

b) - $i$ - caused Umlaut $(a>e)$, just like in Lycian and Carian;

c) Starke 1987: 258 n. 58, cf. 1990: 642 claimed that the initial laryngeal is continued in Pisidian as $\langle\gamma\rangle$. While this is possible, one must mention Melchert's alternative view (2013: 35),

${ }^{21}$ Starke 1999: col. 532 suggested the restoration of the genitive ending, which can be excluded only if the attested Pisidian ending can be derived regularly from an earlier genitive ending, and surely this is the case, whichever suggestion applies.

${ }^{22}$ One may, however, object that according to Rieken apud Miller 2013: 121 Fig. 3 and Rieken (forthcoming) Lydian was a Luwic language, thus this suffix is a feature of the Luwic languages (for an opposing view on Lydian see e.g. Yakubovich 2010: 6). Unfortunately, the relationship of Lydian with the Luwic languages requires further research. 
who sees a secondary assimilation in it: ${ }^{*} k d->g d$-. If the suggestion to connect the first part of Ovyoloss (N37, 3x) with the Luwic element uhha- is correct (Simon 2014: 185), then it shows that one of the reflexes of the intervocalic laryngeals was $\langle\gamma\rangle$. Since this is the voiced counterpart, one expects ${ }^{*} k$ - in initial position, exactly what Melchert proposed. Interestingly enough it would show a laryngeal system identical to that of Lycian, but different from Carian (cf. Simon 2011; Brosch 2016).

d) Pisidian did not lenite the consonant of the suffix - $t i$ - (just like Lycian).

Finally, the lexicon also calls for some comments. Set aside the Lallnamen, the theophoric names, the foreign names, and the names with unintelligible components, the remaining ones show a typical Luwic vocabulary: ${ }^{23}$

\begin{tabular}{|c|c|}
\hline$\Gamma \delta \alpha \beta \alpha / \Gamma \delta \alpha \beta$ о & $<$ *hantawa- (as per above, $\S 2$ ) \\
\hline$\Gamma \delta \alpha \sigma \alpha \varsigma$ & $<$ *hantassa/i- (as per above, $\S 2)$ \\
\hline$\Gamma \delta \varepsilon \beta \varepsilon \tau \iota \varsigma$ & $<$ hantawat $(i)-($ as per above, $\S 2)$ \\
\hline Mova (N34, N38) / Movos (N23, N32) & < muwa- (Brixhe - Drew-Bear - Kaya 1987: 159) \\
\hline Ouүoısıs & < uhha- (Simon 2014: 185) \\
\hline 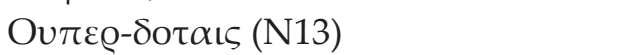 & $<$ upra- (as per above, $\S 5.2$ ) \\
\hline 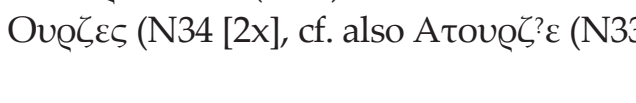 & $\begin{array}{c}<\text { urazza- 'greatest' (suggested here, for this } \\
\text { meaning see Yakubovich 2013, esp. 160-161) }\end{array}$ \\
\hline 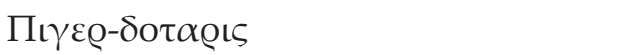 & $<^{*}$ pihra- (as per above, $\left.\S 5.2\right)$ \\
\hline
\end{tabular}

\section{Conclusions}

1. There is no evidence for a specific connection with Hieroglyphic Luwian (contra Starke). Although most of the features could be explained as late, secondary developments from Hieroglyphic Luwian, the non-lenited consonant in the suffix - $t i-$ argues against it, not to mention the geographic distance.

2. Nothing supports that Pisidian has anything special to do with Sidetic (contra Neumann), thus the remark of Livius seems to have a different background. The only assured shared feature is the loss of final -s, but this happens in Milyan and Carian as well.

3. It is probable that Pisidian belongs to the Luwic subgroup (as was already suggested by Zgusta). Nevertheless, lacking enough evidence about the morphology of Pisidian, this is based only on its clear Luwic vocabulary, more precisely, on the Pisidian names that originate in Luwic vocabulary. ${ }^{24}$

4. There are two possibilities regarding its position within the Luwic languages:

a) a member of the Carian - Lycian - Milyan - Pisidian dialect continuum, where the fine differences could be exemplified by the different reflexes of the genitive ending as well as those of the laryngeals;

${ }^{23}$ Note that Ovd (42) is a Lallname "Wa" (with Brixhe - Özsait 2001: 169) and not the Luwian word wawa/i'cow' (contra Lebrun 2012: 360). A full analysis of the entire Pisidian onomastic material is still a desideratum.

${ }^{24}$ In other words, there is still a theoretical possibility that the underlying language is not Luwic or not Anatolian or not even Indo-European that was later culturally or linguistically Luwicized (in the former case these names would show only the emulation of the Luwic culture and not the underlying language, in the latter case the names would represent only a borrowed vocabulary). Nevertheless, a non-Indo-European language is not expected in Pisidia in the first centuries AD. As a non-Anatolian language only Phrygian could be assumed, but this is morphologically not possible, since the Phrygian genitives are quite different. Thus the only real alternative is a non-Luwic Anatolian language. 
b) considering that practically all features are identical to those of Milyan, one may entertain the idea that Pisidian is a late successor of Milyan and both differences (the rise of the epenthetic vowels in ouper- and piger-, and *-nt->-d-) are only due to a later development in Pisidian.

Lacking substantial Pisidian material it is obviously impossible to choose between the alternatives and prudence dictates to opt for the dialect continuum. One can only hope that the recently found longer Pisidian texts will improve the understanding of the position of Pisidian among the Anatolian languages.

\section{Acknowledgements}

This paper was written in the framework of the research project "Los 'dialectos luvicos' del grupo anatolio indoeuropeo: aproximaciones genéticas y areales” (FFI2012-32672) financed by the Ministerio de Economía y Competitividad of Spain. I am very grateful to Elisabeth Rieken and Diether Schürr for sharing their manuscripts with me as well as to Gabriella Juhász for correcting my English.

\section{Literature}

Adiego, Ignacio-J. 1992. Recherches cariennes: essai d'amélioration du systeme de J. D. Ray. Kadmos 31: 25-39.

Adiego, Ignacio J. 2007. The Carian Language. HdO 86. Leiden - Boston: Brill.

Adiego, Ignasi-Xavier. 2012. Minima pisidica. Nota sobre la estructura de una inscripción pisidia de Timbriada. In:

G. Borghello, V. Orioles (eds.). Per Roberto Gusmani. Studi in ricordo 2.: 17-26. Udine: Forum.

Adiego, Ignasi-Xavier. 2016. The longest Pisidian inscription (Kesme 2). Paper held at 'Luwic' Dialects: Inheritance and Diffusion. Barcelona, 9 March 2016.

Allen, W. Sidney. 19873. Vox Graeca. A Guide to the Pronunciation of Classical Greek. Cambridge: Cambridge University Press.

Borchhardt, Jürgen, Günter Neumann, Klaus Schulz. 1975. Vier pisidische Grabstelen aus Sofular. Kadmos 14: 68-72.

Brixhe, Claude. 1987². Essai sur le grec anatolien au début de notre ére. Nancy: Presses Universitaires.

Brixhe, Claude. 1988. La langue des inscriptions epichoriques de Pisidie. In: Y. L. Arbeitman (ed.). A Linguistic Happening in Memory of Ben Schwartz: 131-155. Louvain-la-Neuve: Peeters.

Brixhe, Claude. 2010. Linguistic Diversity in Asia Minor during the Empire: Koine and Non-Greek Languages. In: E. J. Bakker (ed.): A Companion to the Ancient Greek Language: 228-252. Malden - Oxford - Chichester: Wiley-Blackwell.

Brixhe, Claude. 2016a. Au long de l'Eurymédon. Le pisidien. Res Antiquae 13: 29-36.

Brixhe, Claude. 2016b. Stèles et langue de Pisidie. Études anciennes 61. Nancy - Paris: A.D.R.A. - De Boccard.

Brixhe, Claude, Elsa Gibson. 1982. Monuments from Pisidia in the Rahmi Koç Collection. Kadmos 21: 130-169.

Brixhe, Claude, Mehmet Özsait. 2001. Nouvelles inscriptions pisidiennes et grecques de Timbriada. Kadmos 40: 155-176.

Brixhe, Claude, Mehmet Özsait. 2013. Course moyen d'Eurymedon: apparition du pisidien. In: H. Bru, G. Labarre (eds.). L'Anatolie des peuples, des cités et des cultures (II millénaire av. J.-C. - Ve siècle ap. J.-C.). Colloque international de Besançon - 26-27 Novembre 2010 2. Approches locales et regionals: 231-250. Besançon: Presses universitaires de Franche-Comté.

Brixhe, Claude, Thomas Drew-Bear, Durmuş Kaya. 1987. Nouveaux monuments de Pisidie. Kadmos 26: $122-170$.

Brosch, Cyril. 2016. Zur Vertretung der Laryngale im Karischen. In: H. Marquardt, S. Reichmuth, J. V. García Trabazo (eds.). Anatolica et indogermanica. Studia linguistica in honorem Johannis Tischler septuagenarii dedicata: 7-12. Innsbruck: Institut für Sprachen und Literaturen der Universität Innsbruck Bereich Sprachwissenschaft.

Haas, Otto. 1961. Armenier und Phryger. Linguistique Balkanique 3/2: 29-65.

Hajnal, Ivo. 1994. Die lykischen a-Stämme: Zum Werdegang einer Nominalklasse. In: J. E. Rasmussen (ed.). In honorem Holger Pedersen. Kolloquium der Indogermanischen Gesellschaft vom 25. bis 28. März in Koppenhagen: 135-171. Wiesbaden: Reichert. 
Hajnal, Ivo. 1995. Der lykische Vokalismus. Methode und Erkenntnisse der vergleichenden anatolischen Sprachwissenschaft, angewandt auf das Vokalsystem einer Kleincorpussprache. Graz: Leykam.

Hajnal, Ivo. 2000. Der adjektivische Genitivausdruck der luwischen Sprachen (im Lichte neuerer Erkenntnisse). In: M. Ofitsch, Chr. Zinko (eds.). 125 Jahre Indogermanistik in Graz. Festband anläßlich des 125jährigen Bestehens der Forschungsrichtung "Indogermanistik” an der Karl-Franzens-Universität Graz: 159-184. Graz: Leykam.

Houwink ten Cate, Philo H. J. 1961. The Luwian Population Groups of Lycia and Cilicia Aspera during the Hellenistic Period. DMOA 10. Leiden: Brill.

Kloekhorst, Alwin. 2011. The accentuation of the PIE word for 'daughter'. In: T. Pronk, R. Derksen (eds.). Accent Matters. Papers on Balto-Slavic Accentology. Studies in Slavic and General Linguistics 37.: 235-243. Leiden: Brill.

König, Friedrich Wilhelm. 1936. Die Stele von Xanthos I. Metrik und Inhalt. Klotho - Historische Studien zu feudalen und vorfeudalen Welt 1 . Wien: Gerold.

Laroche, Emmanuel. 1966. Les noms des hittites. Paris: Klincksieck.

Lebrun, René. 1983. Notes d'onomastique gréco-asianique. Hethitica 5: 63-74.

Lebrun, René. 2012. Le sidétique et le pisidien. Res Antiquae 9: 353-368.

Melchert, H. Craig. 1994a. Anatolian Historical Phonology. LSIE 3. Amsterdam - Atlanta: Rodopi.

Melchert, H. Craig. 1994b. Anatolian. In: F. Bader (ed.). Langues indo-européennes: 121-136. Paris: CNRS.

Melchert, H. Craig. 2003a. Introduction. In: id. (ed.). The Luwians. HdO 68.: 1-7. Leiden - Boston: Brill.

Melchert, H. Craig. 2003b. Language. In: id. (ed.). The Luwians. HdO 68.: 170-210. Leiden - Boston: Brill.

Melchert. H. Craig. 2012. Genitive Case and Possessive Adiective in Anatolian. In: G. Borghello, V. Orioles (eds.). Per Roberto Gusmani. Studi in ricordo 2.: 273-286. Udine: Forum.

Melchert, H. Craig. 2013. Naming Practices in Second- and First-Millennium Western Anatolia. In: R. Parker (ed.). Personal Names in Ancient Anatolia. Proceedings of the British Academy 191.: 31-49. London: British Academy.

Metri, Pino. 1958. Le iscrizioni pisidiche di Sofoular. Archivio Glottologico Italiano 43: 42-54.

Miller, Jared L. 2013. Hititler Dönemi'nde Anadolu'da Halklar ve Diller / Peoples and Languages in Anatolia during the Hittite Period. In: M. Doğan-Alparslan, M. Alparslan (eds.). Hititler. Bir Anadolu Imparatorluğu / Hittites. An Anatolian Empire. Anadolu Uygarlıkları / Anatolian Civilizations 3.: 120-131. İstanbul: Yap1 Kredi.

Neumann, Günter. 1978. Die sidetische Schrift. Annali della Scuola Normale Superiore di Pisa Classe di lettere e filosofia. Serie III. 8/3: 869-886.

Neumann, Günter, Elisabeth Fuhrmann. 2005. Zwei epichorische Inschriften aus dem pisidischen Bergland. Kadmos 44: 7-18.

Oettinger, Norbert. 1978. Die Gliederung des anatolischen Sprachgebietes. Zeitschrift für vergleichende Sprachforschung 92: 74-92.

Ramsay, W. M. 1895. Inscriptions en langue pisidienne. Revue des Universités du Midi 1: 353-362.

Rieken, Elisabeth. Forthcoming. The dialectology of Anatolian. In: M. Fritz, B. D. Joseph, J. Klein (eds.). Comparative Indo-European Linguistics. An International Handbook of Language Comparison and the Reconstruction of IndoEuropean. HSK.

Rieken, Elisabeth, David Sasseville. 2014. Social Status as a Semantic Category of Anatolian: The Case of PIE *-wo-. In: H. C. Melchert, E. Rieken, Th. Steer (eds.): Munus amicitiae. Norbert Oettinger a collegis et amicis dicatum: 302-314. Ann Arbor - New York: Beech Stave.

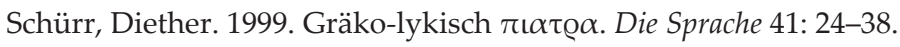

Schürr, Diether. 2001. Karische und lykische Sibilanten. Indogermanische Forschungen 106: 94-121.

Schürr, Diether. 2006. Elf lydische Etymologien. In: Raffaella Bombi et al. (eds.). Studi linguistici in onore di Roberto Gusmani: 1569-1587. Alessandria: dell'Orso.

Schürr, Diether. Forthcoming. Vom Aussterben der luwischen ziti-Namen, lykisch Ipresida und dem Berg Imbros bei Kaunos.

Simon, Zsolt. 2011. Die Fortsetzung der Laryngale im Karischen. In: Th. Krisch, Th. Lindner (eds.). Indogermanistik und Linguistik im Dialog. Akten der XIII. Fachtagung der Indogermanischen Gesellschaft vom 21. bis 27. September 2008 in Salzburg: 538-547. Wiesbaden: Reichert.

Simon, Zsolt. 2014. Review of G. Borghello, V. Orioles (eds.). Per Roberto Gusmani. Studi in ricordo 1-2. Incontri LinQuistici 37: 183-188.

Starke, Frank. 1987. Die Vertretungen von idg. * $d^{h} u g h$,tér- „Tochter“ in den luwischen Sprachen und ihre Stammbildung. Zeitschrift für vergleichende Sprachforschung 100: 243-269. 
Starke, Frank. 1990. Untersuchung zur Stammbildung des keilschrift-luwischen Nomens. StBoT 31. Wiesbaden: Harrassowitz.

Starke, Frank. 1997. Troia im Kontext des historisch-politischen und sprachlichen Umfeldes Kleinasiens im 2. Jahrtausend. Studia Troica 7: 447-487.

Starke, Frank. 1999. Luwisch. DNP 7: cols. 528-534.

Sundwall, Johannes. 1913. Die einheimischen Namen der Lykier nebst einem Verzeichnis kleinasiatischer Namenstämme. Klio Beiheft XI. Leipzig: Dieterich.

Vernet Pons, Mariona. 2012. The Etymology of Goliath in the Light of Carian PN Wljat/Wliat: A New Proposal. Kadmos 51: 143-164.

Yakubovich, Ilva. 2010. Sociolinquistics of the Luvian Lanquage. BSIELL 2. Leiden - Boston: Brill.

Yakubovich, Ilya. 2013. The degree of comparison in Luwian. Indogermanische Forschungen 118: 155-168.

Zgusta, Ladislav. 1957. Die pisidischen Inschriften. Archiv Orientální 25: 570-610.

Zgusta, Ladislav. 1963. Die epichorische pisidische Anthroponymie und Sprache. Archiv Orientální 31: 470-482.

Zgusta, Ladislav. 1964. Kleinasiatische Personennamen. Prag: Tschechoslowakische Akademie der Wissenschaften.

Жолт Шимон. О некоторых проблемах писидийского языка и о его месте среди других анатолийских языков

В статье рассмотрены три проблемы писидийского языка и их влияние на определение положения писидийского внутри анатолийских языков. Эти проблемы таковы: проис-

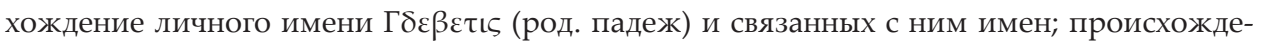
ние личного имени Моvбұ $\alpha$; вопрос о том, засвидетельствован ли в писидийском дательный падеж. Автор полагает, что писидийский - лувический язык, но не потомок иероглифического лувийского, а либо часть карийско-ликийско-милийского диалектного континуума, либо поздняя форма милийского.

Ключевые слова: писидийский язык, лувические языки, иероглифический лувийский, милийский язык, имена собственные. 